\title{
Pesquisa de Salmonella e das condições sanitárias em frangos e lingüiças comercializados na cidade de Botucatu
}

\author{
Vera Lúcia Mores RALL ${ }^{1}$ \\ José Guilherme Prado \\ MARTIN $^{1}$ \\ João Manuel Grisi CANDEIAS ${ }^{1}$ \\ Karen Franco Godoy \\ CARDOSO $^{1}$ \\ Márcia Guimarães da SILVA² \\ Ricardo RALL ${ }^{3}$ \\ João Pessoa ARAÚJO \\ JÚNIOR ${ }^{1}$
}

Correspondência para:

CP 510, CEP 18618-000. Botucatu/SP;

vlmores@ibb.unesp.br

Recebido para publicação: 07/11/2007 Aprovado para publicação: 27/11/2008

\author{
1 - Departamento de Microbiologia e Imunologia da Universidade Estadual \\ Paulista, Botucatu-SP \\ 2 - Departamento de Patologia da Faculdade de Medicina da Universidade \\ Estadual Paulista, Botucatu-SP \\ 3 - Faculdade de Tecnologia, Botucatu-SP
}

\section{Resumo}

O objetivo do trabalho foi avaliar as condições sanitárias de frango e diversos tipos de lingüiças comercializados na cidade de Botucatu, São Paulo, pela determinação do número mais provável de coliformes a $45^{\circ} \mathrm{C} / \mathrm{g}$ além da pesquisa de Salmonella pela metodologia tradicional e pela PCR. Foram coletadas 50 amostras de carcaça de frango e 75 de lingüiças frescais, procedentes de nove estabelecimentos diferentes da cidade, no período de abril a novembro de 2006. Das 50 amostras de frango, $35(70 \%)$ estavam fora dos parâmetros microbiológicos, segundo a RDC n ${ }^{\circ} 12$ da Anvisa $\left(>10^{4}\right.$ coliformes a $\left.45^{\circ} \mathrm{C} / \mathrm{g}\right)$. Embora nessa Resolução, a pesquisa de Salmonella não seja exigida, 4 amostras (8\%) apresentaram o patógeno pela metodologia tradicional. Essa presença foi confirmada pela PCR, que também foi positiva para mais 23 amostras, num total de 27 positivas (54\%). Dentre as 75 amostras de lingüiças, 30 (40\%) estavam fora dos limites permitidos, com 7 amostras positivas para Salmonella, pela metodologia tradicional. Entretanto, se considerar-se a pesquisa pela PCR, o número de amostras positivas aumenta para 42 (56\%). Somando-se a taxa de freqüência de Salmonella aos limites microbiológicos para coliformes a $45^{\circ} \mathrm{C}, 86,7 \%$ das lingüiças analisadas estavam impróprias para o consumo.

\section{Introdução}

O hábito de consumo de carne de frango por parte dos brasileiros vem mudando devido à queda gradual de preço, à boa qualidade e à praticidade dos produtos oferecidos. Nesse período, o consumo per capita aumentou de $10 \mathrm{~kg}$ para $35,4 \mathrm{~kg}$, ficando pouco abaixo do consumo de carne bovina $(36,3 \mathrm{~kg}) \cdot{ }^{1}$ Quanto à produção, o Brasil é o segundo maior produtor e o maior exportador mundial de carne de frango, com $41 \%$ de participação no comércio internacional. A carne de porco é a terceira mais consumida no Brasil e, apesar de representar apenas um terço do consumo de carne de frango/bovina, os $11,3 \mathrm{~kg}$ consumidos per capita ainda é valor considerável. Destes, cerca de $70 \%$ são comercializados na forma de embutidos, principalmente como lingüiças. ${ }^{2}$

Tendo em vista o grande consumo de carnes e a tendência mundial desse aumento, a qualidade desses produtos é extremamente importante, sendo uma preocupação dos órgãos de saúde pública, das indústrias alimentícias e dos próprios consumidores. As aves criadas para consumo humano podem ser hospedeiras naturais de vários microrganismos patogênicos, como Campylobacter jejuni, Salmonella sp e E. coli .3,4

A Salmonella apresenta amplo espectro de hospedeiros, principalmente aves. ${ }^{5} \mathrm{O}$ gênero compreende bacilos Gram-negativos 
não produtores de esporos, anaeróbios facultativos e a maioria é móvel (exceção de $S$. Pullorum e $S$. Gallinarum). Essa bactéria representa um dos maiores perigos à indústria alimentícia, pois é um agente etiológico causador de gastrenterites. ${ }^{6} \mathrm{O}$ período de incubação da salmonelose é, em média, de 48 horas e os alimentos mais frequentemente implicados são os de origem animal, particularmente carnes de frango, ovos e alimentos mal cozidos.

No Brasil, a subnotificação de casos de infecções por Salmonella representa um grave problema, pois os números divulgados pelos órgãos de vigilância sanitária parecem não corresponder à realizadade. Mesmo assim, estimativas sobre a frequência de infecções por Salmonella permitem sugerir um coeficiente de casos de 145/100.000 habitantes ${ }^{7}$, número muito superior ao encontrado em países como Portugal, Inglaterra e Alemanha (4,5; 28 e 93,3/ 100.000 habitantes, respectivamente) ${ }^{8}$.

Análises microbiológicas aplicadas à cadeia de produção de alimentos têm por objetivo minimizar os riscos de infecção nos consumidores e atestar a qualidade dos produtos comercializados. Metodologias tradicionais para detecção de patógenos consistem de enriquecimento e isolamento de colônias de microrganismos em meios de cultura apropriados ${ }^{9}$, necessitando-se vários dias para que se obtenham resultados confiáveis. Métodos convencionais de isolamento usados para Salmonella incluem pré-enriquecimento em meio não-seletivo, seguido de enriquecimento seletivo e semeadura em, pelo menos dois ágars seletivos. Colônias suspeitas são confirmadas bioquímica e sorologicamente, somando-se até sete dias para a obtenção de resultados positivos. ${ }^{10}$ Além disso, a sensibilidade desta metodologia pode ser menor do que as baseadas na detecção de DNA, devido à inabilidade do crescimento de células injuriadas ou que estiverem no estado "viável não cultivável". ${ }^{11}$ Por outro lado, métodos moleculares baseados em amplificação de DNA, pela PCR (Reação em Cadeia da Polimerase) é uma alternativa viável para a detecção de microrganismos em amostras de alimentos, sendo a rapidez, especificidade e sensibilidade suas maiores vantagens. Entretanto, a susceptibilidade às substâncias inibitórias presentes em amostras com matrizes complexas, como alimentos, pode ser uma desvantagem ${ }^{11}$. Para se evitar resultados falso-positivos e diluir possíveis substâncias inibidoras, recomenda-se o emprego de, pelo menos, um préenriquecimento não seletivo ${ }^{11}$. Também deve ser considerada, a detecção de moléculas de DNA liberadas pela morte bacteriana, no caso de alimentos submetidos a processamentos térmicos. Salmonella têm-se mostrado bastante sensível a essa ferramenta, necessitando, porém, de procedimentos de enriquecimento para se aumentar essa sensibilidade. ${ }^{12} \mathrm{O}$ método é evidentemente vantajoso se comparado ao convencional, demorado e trabalhoso, visto que a rapidez no diagnóstico da qualidade dos produtos a serem comercializados é de grande interesse das redes de produção de alimentos.

O objetivo do presente trabalho foi avaliar as condições higiênico-sanitárias de carne de frango e diversos tipos de lingüiças comercializados na cidade de Botucatu, estado de São Paulo, pela determinação do Número Mais Provável (NMP) de coliformes a $45^{\circ} \mathrm{C}$, além da pesquisa de Salmonella pela metodologia tradicional e pela PCR.

\section{Material e Método}

Foram coletadas 50 amostras de carne de frango e 75 de lingüiças frescais, procedentes de nove estabelecimentos diferentes da cidade de Botucatu, São Paulo, no período de abril a agosto de 2006 e as carcaças foram mantidas nas embalagens de comercialização e transportadas imediatamente até o laboratório, sob refrigeração, em caixas isotérmicas.

Para a análise, 25 gramas da amostra foram homogeneizados em $225 \mathrm{ml}$ de água tamponada peptonada 1\% (Stomacher Lab Blender 400). A partir desta diluição inicial de $10^{-1}$, foram preparadas várias diluições 
decimais, utilizando-se o mesmo diluente.

Para enumeração de coliformes a $45^{\circ} \mathrm{C}$, foi utilizada a técnica dos tubos múltiplos, semeando-se em triplicata, volumes de $1 \mathrm{~mL}$ de diluições seqüenciais em caldo lauril sulfato (Difco, EUA, Sparks) com um tubo de Durham invertido. Os tubos foram incubados a $35^{\circ} \mathrm{C} / 48 \mathrm{~h}$. Nos inóculos positivos foi observada a produção de gás no tubo de Durham e os tubos positivos foram repicados para caldo E.C. (Difco), para a confirmação de coliformes a a $45^{\circ} \mathrm{C}$, incubados nessa temperatura/24 h, em banho-maria. A leitura ocorreu pela observação da presença de gás no tubo de Durham invertido. Utilizou-se uma tabela para o cálculo do Número Mais Provável (NMP) de colifomres a $45^{\circ} \mathrm{C}$ por grama de amostra analisada ${ }^{13}$.

Para a detecção da presença de Salmonella, 25 gramas de amostra foram homogeneizados em $225 \mathrm{~mL}$ de água peptonada $1 \%$, no "Stomacher", com incubação a $35^{\circ} \mathrm{C} / 24 \mathrm{~h}$. Em seguida, foi transferido $1 \mathrm{~mL}$ do homogeneizado para um tubo com $10 \mathrm{~mL}$ de caldo tetrationato (Difco), suplementado imediatamente antes do uso com $0,2 \mathrm{ml}$ de solução de iodo e incubado a $35^{\circ} \mathrm{C} / 24 \mathrm{~h}$. Outra alíquota de $0,1 \mathrm{~mL}$ foi transferida para um tubo com $10 \mathrm{~mL}$ de caldo Rapapport (Difco), incubado a $42^{\circ} \mathrm{C} / 24$ horas. Após este período, uma alçada de cada tubo foi semeada em placas de Petri contendo ágar XLD (xilose-lisina-desoxicolato- Difco) e ágar SS (Salmonella-Shigella-Difco), incubadas a $35^{\circ} \mathrm{C} / 24 \mathrm{~h}$. As colônias características de Salmonella repicadas para tubos de ágar tripticase soja inclinado (TSA- Difco), incubados a $35^{\circ} \mathrm{C} / 24 \mathrm{~h}$. A partir dessas cepas estoque foram realizados os testes bioquímicos com agar TSI (Agar Tríplice Açúcar Ferro- Difco) e agar Fenilalanina (Difco) Após a leitura desses testes preliminares, as cepas suspeitas foram submetidas a API 20 E (Biomerieux, França, Paris) e, a seguir, foi realizada a solorogia com soros anti antígeno somático e flagelar (Probac, Brasil, São Paulo). ${ }^{14}$

Paralelamente, a partir dos caldos de enriquecimento ocorreu a pesquisa da presença de Salmonella pela PCR. Assim, 1 $\mathrm{ml}$ dos caldos Tetrationato e RapapportVassiliadis, foi centrifugado a $10.000 \mathrm{~g} / 10$ minutos. O sobrenadante era desprezado e o sedimento, ressuspendido em $1 \mathrm{ml}$ de PBS (Solução Tampão de Fosfato 0,01 M, pH $7,2)$. Esse passo foi repetido mais duas vezes, com tempo de centrifugação de 5 minutos. A seguir, o sedimento foi ressuspendido em 200 il de tampão de lise $(50 \mathrm{mM}$ Tris- $\mathrm{H}-\mathrm{Cl}$, $1 \mathrm{mM}$ EDTA 0,025\% Tween, 0,2 mg proteinase $\mathrm{K}$ ) incubado em banho-maria a $56^{\circ} \mathrm{C} / 1$ hora e depois, a $95^{\circ} \mathrm{C} / 10$ minutos. Ocorreu nova centrifugação a $13.000 \mathrm{~g} / 5$ minutos e o sobrenadante foi usado para a reação da PCR. ${ }^{11}$

Para as reações de PCR foram utilizados tubos de microcentrífuga (Axygen, Estados Unidos, Union City) num volume total de $25 \mu \mathrm{L}$, composto por $2,5 \mu \mathrm{L}$ de PCR Buffer 10x (Invitrogen, Estados Unidos, Carlsbad), 0,75 $\mu \mathrm{M}$ de Cloreto de Magnésio (Invitrogen), $200 \mu \mathrm{M}$ de cada dNTP (Invitrogen), $1 \mathrm{U}$ de Taq DNA Polimerase (Invitrogen), 10 picomoles de cada primer, água ultrapura autoclavada (qsp) (Milli-Q Plus, Millipore) e $3 \mu \mathrm{L}$ da amostra de DNA. A incubação foi realizada em termociclador PTC-100 (MJ Research, Inc.) empregando-se os parâmetros de um ciclo inicial a $94^{\circ} \mathrm{C}$ durante 5 minutos para desnaturação inicial, seguidos por 35 ciclos $\operatorname{com} 94^{\circ} \mathrm{C} / 30$ s, $60^{\circ} \mathrm{C} / 30$ s e $72^{\circ} \mathrm{C} / 30$ s. A temperatura de extensão final foi de $72^{\circ} \mathrm{C}$ por 4 minutos. Em todas as reações realizadas foi utilizado um controle negativo, através da substituição da amostra por água ultrapura. Como controle positivo, foi utilizada uma cepa padrão de Salmonella Choleraesuis ATCC 13076 e como negativo, a amostra foi substituída por água ultrapura esterilizada. $O$ par de primers utilizado codifica para o gene inv $A$, com a seguinte seqüência: invA1: TCATCGCACCGTCAAAGGAAC e invA2: GTGAAATTATCGCCACGTTCGG, gerando um produto de $284 \mathrm{pb}^{11}$

Os produtos das reações de PCR foram submetidos à eletroforese 
(Electrophoresis Power Supply Model EPD 600 - Amersham-Pharmacia Biotech Inc.) em gel de agarose 1,5\% (Sigma Aldrich) em tampão de ácido bórico-Tris-EDTA (TBE) e revelados com brometo de etídio $(0,5 \mathrm{mg} /$ $\mathrm{ml}$ - Invitrogen). Os fragmentos de DNA foram analisados comparativamente com marcadores de DNA de 50 bp (GE Healthcare), sendo analisados e fotografados em analisador de imagens (Alphaimager Alpha esasy FC Software - AlphaInotech Corporation).

As proporções de positividade de Salmonella no frango foram analisadas pelo teste de Comparação de Proporção entre dois grupos (Teste Z, $5 \%$ ). ${ }^{15}$

\section{Resultados}

Foram analisadas 50 amostras de carne de frango, onde $35(70 \%)$ estavam fora dos parâmetros microbiológicos, segundo a RDC nº12 da Agência Nacional de Vigilância Sanitária (ANVISA) ${ }^{16}$ (até $10^{4}$ coliformes a $45^{\circ} \mathrm{C} / \mathrm{g}$ ). Embora a pesquisa da presença de Salmonella não seja exigida, 4 $(8 \%)$ amostras apresentaram o patógeno pela metodologia tradicional. Essa presença foi confirmada pela PCR, que também foi positiva para mais 23 amostras, num total de 27 positivas $(54 \%)$ nessa metodologia $(\mathrm{z}$ $=4,757 ; \mathrm{p}<0,001)$. Os primers utilizados nesse trabalho, na ánalise pela PCR, geraram os produtos observados na figura 1 .

Os padrões microbiológicos para lingüiças frescais ${ }^{16}$ permitem até $5 \times 10^{3}$ de coliformes a $45^{\circ} \mathrm{C} / \mathrm{g}$ e não toleram a presença de Salmonella em $25 \mathrm{~g}$ do alimento. Entre as 75 amostras de lingüiças, 30 (40\%) estavam fora dos limites permitidos, devido excesso de coliformes, com 7 amostras também positivas para Salmonella $(9,3 \%)$, pela metodologia tradicional. Entretanto, se for considerada a pesquisa pela PCR, o número de amostras positivas aumenta para $42(56 \%)(z=5,924 ; p<0,001)$. Somandose a taxa de frequêencia de Salmonella aos limites microbiológicos para coliformes a $45^{\circ} \mathrm{C}, 86,7 \%$ das lingüiças analisadas estavam impróprias para o consumo.

\section{Discussão}

Apesar dos coliformes a $45^{\circ} \mathrm{C}$ serem o único padrão microbiológico da carne de frangos, poucos trabalhos no Brasil relatam esse tipo de contaminação. Em 2002, Silva et al. ${ }^{17}$ pesquisaram 60 cortes de frangos adquiridos no comércio de João Pessoa (PB) e $100 \%$ apresentaram coliformes a $45^{\circ} \mathrm{C}$. Recentemente, em 2005, Cardoso et al. ${ }^{18}$ observaram somente $26 \%$ de amostras impróprias para consumo entre as 35 analisadas, número inferior ao encontrado

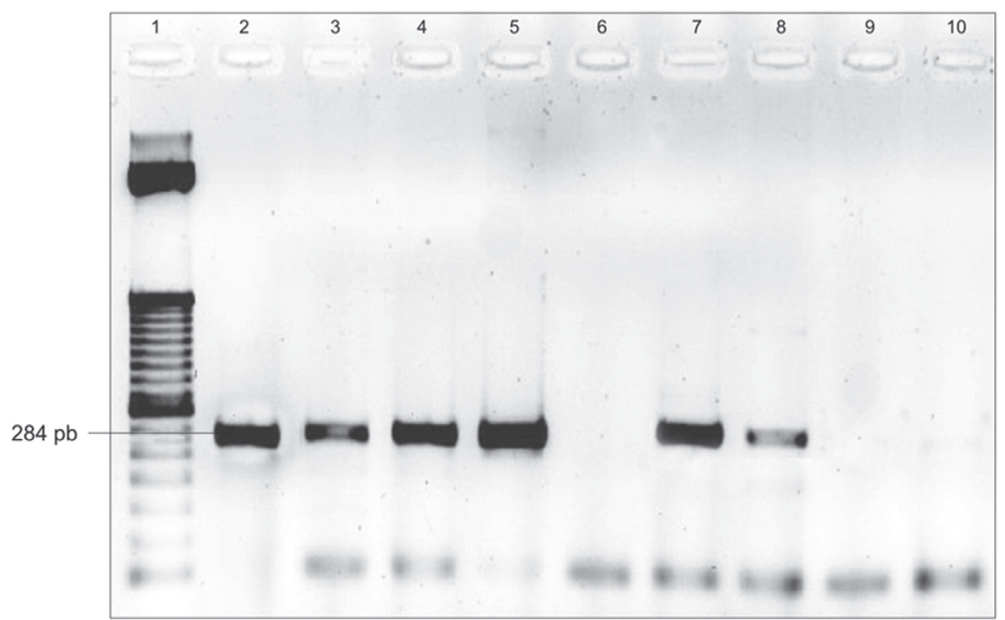

Figura 1 - Gel de eletroforese do produto da PCR do gene invA. Poço 1: marcador de pares de base (50bp); poço 2: Salmonella Choleraesuis ATCC 13706; poços 3, 4, 5, 7 e 8: amostras positivas; poços 6 e 9: amostras negativas; poço 10: controle negativo 
no presente estudo, de $70 \%$.

A ocorrência de Salmonella em carne de frango (carcaças e cortes) pode variar consideravelmente. Esta variação pode estar realacionada com a procendência do lote (contaminação primária), condições higiênico-sanitárias do abatedouro, contaminação cruzada durante as etapas do abate, além do transporte e comercialização. ${ }^{19}$

Pela metodologia tradicional, esse trabalho observou freqüência de $8 \%$, quanto à presença de Salmonella. Cardoso et al. ${ }^{18} \mathrm{e}$ Baú, Carvalho e Aleixo ${ }^{20}$ apresentaram resultados semelhantes aos encontrados nessa pesquisa, com a presença de Salmonella em, respectivamente, $10,5 \%$ e $11,4 \%$ das amostras analisadas. Carvalho e Cortez ${ }^{21}$ relataram taxas maiores, de $20 \%$ de positividade.

A maioria dos trabalhos publicados que apresenta níveis de freqüência de Salmonella não ultrapassa 30\% em amostras de carne de frango, utilizando-se a metodologia tradicional. No Brasil, Gonçalves, Franco e Zamborlini ${ }^{22}$ observaram que $26,7 \%$ das amostras procedentes do estado do Rio de Janeiro estavam contaminadas com o patógeno. Valor semelhante foi observado na Inglaterra por Jorgensen et al. ${ }^{23}$, que encontraram $25 \%$ de amostras positivas. Em Maryland, Estados Unidos, Myint et al. ${ }^{24}$ observaram taxas que variaram de 22 a $28 \%$. Segundo Mattick et al. ${ }^{25}$ um dos principais problemas no isolamento de Salmonella é o pequeno número dessa bactéria, em relação à quantidade de outras bactérias competidoras.

A freqüência foi bem maior quando foi utilizada a PCR como ferramenta. Almeida Filho et al. ${ }^{26}$ encontraram uma taxa de 45\% (18/40) de amostras de frango contaminadas por Salmonella em Cuiabá, número próximo ao encontrado pela presente pesquisa $(54 \%)$.

$\mathrm{Na}$ enumeração de coliformes a $45^{\circ} \mathrm{C}$ em lingüiças frescais, o presente estudo encontrou 30 amostras impróprias para o consumo (40\%), número muito superior ao relatado por Salvatori, Bessa e Cardoso ${ }^{27}$, de 7\%, em Porto Alegre (RS). Entretanto, Marques et al. ${ }^{28}$, pesquisaram 40 amostras desse alimento em Lavras e Três Corações (MG) e 35\% estavam com concentrações de coliformes a $45^{\circ} \mathrm{C}$ acima dos limites permitidos pela ANVISA ${ }^{16}$.

Em relação à pesquisa de Salmonella pela metodologia tradicional, os números relatados na bibliografia variam bastante. Giovannini et al. ${ }^{29}$ observaram taxa de $17,6 \%$ de amostras positivas em lingüiças comercializadas na região de Abruzzi, Itália, enquanto que Mrema, Mpuchane e Gashe ${ }^{30}$ encontraram o patógeno em $26 \%$ das amostras procedentes do comércio de Gaborone, Botswana, números acima dos encontrados pela presente pesquisa $(7,5 \%)$.

Porém, a positividade de Salmonella foi bem maior quando a metodologia adotada foi a PCR. Castagna et al. ${ }^{31}$ relatam a presença do patógeno em $66 \%$ das amostras (25/38) de lingüiças frescais provenientes da região sul do Brasil, número pouco acima do encontrado pelo presente estudo, de $56 \%$.

Em relação às metodologias empregadas, pode-se concluir que a PCR mostrou-se mais sensível que a tradicional. É importante acrescentar que a metodologia de PCR mostra-se realmente eficaz quando as amostras são submetidas anteriormente a um período de enriquecimento. Myint et al. ${ }^{24}$ obtiveram resultados satisfatórios com um período mínimo de enriquecimento de 8 horas, diferentemente de outros autores que advertem que são necessárias 10 horas, no mínimo, para a plena eficácia da metodologia. ${ }^{32} \mathrm{O}$ presente trabalho utilizou 24 horas de enriquecimento, tempo igual a metodologia tradicional.

Como já foi observado por outros autores ${ }^{26,31}$, a frequência de detecçao de Salmonella aumentou quando se utilizou a PCR. A possibilidade de ter ocorrido detecção de DNA liberado de células mortas é pequena. Primeiramente, porque as amostras não foram previamente submetidas a nenhum tratamento que reduzisse a contaminação com morte da microbiota (temperatura ou irradiação), além disso, essa técnica foi positiva em todas as amostras 
onde a Salmonella também havia sido isolada pela metodologia tradicional. Também deve ser considerado que a PCR, uma vez padronizada adequadamente, apresenta grande reprodutibilidade, se realizada com critério. $\mathrm{Na}$ metodologia tradiocional, a observação e senso crítico, no momento da leitura das placas de isolamento tem ser constantes, podendo ocorrer erros de interpretação mais frequentemente.

Pelos resultados obtidos, pode-se concluir que esses alimentos representam perigo à saúde dos consumidores, sendo necessárias medidas para um maior controle e fiscalização por parte das autoridades de vigilância sanitária, a fim de que se reduzam os índices de freqüência de Salmonella em carne de frango e lingüiças frescais.

\section{Research of Salmonella and sanitary conditions in poultry and sausages retailed in Botucatu}

\section{Abstract}

In the present investigation were evaluated the sanitary conditions of poultry and several types of sausages retailed in Botucatu, São Paulo, Brazil for the determination of the most probable number of coliforms at $45^{\circ} \mathrm{C} / \mathrm{g}$ besides the research of Salmonella using traditional methodology and PCR. In order to do so, 50 samples of poultry and 75 of sausages were collected from nine different establishments in the city, in the period of April to November of 2006. Of the 50 samples of chicken meat, $35(70 \%)$ were out of the microbiologic parameters, according to Brazilian Sanitary Resolution RDC n ${ }^{\circ} 12$ of Anvisa $\left(>10^{4}\right.$ coliforms at $\left.45^{\circ} \mathrm{C} / \mathrm{g}\right)$. In this Resolution, the research of Salmonella is not demanded, but 4 samples $(8 \%)$ presented the pathogen using the traditional methodology. That presence was confirmed by PCR, which was also positive in another 23, in a total of 27 positive samples (54\%). Among 75 samples of sausages, $30(40 \%)$ were out of the allowed limits, with 7 positive samples for Salmonella, using traditional methodology. However, if we consider PCR test, the number of positive samples increases to 42 (56\%). Adding this number to coliforms microbiological limits, $86.7 \%$ of the analyzed sausages were inappropriate for the consumption.

\section{Referências}

1 UNIÃO BRASILEIRA DE AVICULTURA. Relatório anual 2005-2006. Disponível em <http:// www.uba.org.br/ubanews files/ rel_uba_2005_06.pdf >. Acesso em: 30 out. 2008.

2 ZOOTEC, 2004, Brasília. Carne de porco agora é símbolo de qualidade. Disponível em : < http:// www.upis.br/zootec2004/noticias3.asp >. Acesso em: 30 out. 2008

3 LUCEY, B.; FEURER, C.; GREER, P.; MOLONEY, P.; CRYAN, B.; FANNING, S. Antimicrobial resistence profiling and DNA Amplification Fingerprint (DAF) of thermophilic Campylobacter spp. in human, poultry and porcine samples from the Cork region of Ireland. Journal of Applied Microbiology, v. 89, n. 5, p. 727734, 2000.

4 NATRAIAN, N.; SHELDON, B. W. Inhibition of
Key words: Poultry.

Sausage.

Coliforms. Salmonella. PCR.
Salmonella on poultry skin using protein and polysaccharide-based films containing a nisin formulation. Journal of Food Protection, v. 63, n. 9, p. 1268-1272, 2000.

5 WAAGE, A. S.; VARDUND, T.; LUND, V.; KAPPERUD, G. Detection of low numbers of Salmonella in environmental water, sewage and food samples by a nested polymerase chain reaction assay. Journal of Applied Microbiology, v. 87, n. 3, p. 418428, 1999.

6 SIQUEIRA, R. S.; DODD, C. E. R.; REES, C. E. D. Phage amplification assay as rapid method for Salmonella detection. Brazilian Journal of Microbiology, v. 34, p. 118-120, 2003. Supplement.

7 EDUARDO, M. B. P.; KATSUYA, E. M.; BASSIT, N. P.; MELLO, M. L. R. Salmonella enteritis: uma importante causa de surtos bacterianos veiculados por alimentos e a necessidade de uma nova regulamentação 
sanitária para alimentos implicados, São Paulo, Brasil, 1999-2003. Boletim Epidemiológico Paulista, v. 1, n. 8, 2004. Disponível em: <http:// w w w. c ve.saude.sp.gov.br/agencia/ bepa8_salmo9903.htm >. Acesso em: 20 de set. 2006.

8 WHO 1999-2000. Disponível em: <http:// www.bfr.bund.de/internet/8threport/8threp fr.htm $>$. Acesso em: 10 nov. 2006.

9 CORRY, J. E.; POST, P. C.; LAISNEY, M. J. Culture media for the isolation of campylobacters. International Journal of Food Microbiology, v. 26, n. 1, p. 43-76, 1995.

10 BENNET, A. R.; GREENWOOD, D.; TENNANT, C.; BANKS, J. G.; BETTS, R. P. Rapid and definitive detection of Salmonella in foods by PCR. Letters of Applied Microbiology, v. 26, n. 6, p. 437-441, 1998.

11 ARNOLD, T.; SCHOLZ, H. C.; MARG, H.; ROSLER, U.; HENSEL, A. Impact of invA-PCR and culture detection methods on occurrence and survival of salmonella in the flesh, internal organs and lymphoid tissues of experimentally infected pigs. Journal of Veterinary Medicine series B, v. 51, n. 10, p. 459-463, 2004.

12 NIEROP, W.; DUSÉ, A. G.;MARAIS, E.; AITHMA, N.; THOTHOBOLO, N.; KASSEL, M.; STEWART, R.; POTGIETER, A.; FERNANDES, B.; GALPIN, S. J.; BLOOMFIELD, S. F. Contamination of chicken carcasses in Gauteng, South Africa, by Salmonella, Listeria monocytogenes and Campylobacter. International Journal of Food Microbiology, v. 99, n. 1, p. 1-6, 2005.

13 KORNACKI, J. L.; JOHNSON, J. L. Enterobacteriaceae, coliforms, and Escherichia coli as quality and safety indicators. In: DOWNES, F. P.; ITO, $\mathrm{K}$. Compendium of methods for the microbiological examination of foods. 4. ed. Washington: APHA, 2001. p. 69-82.

14 ANDREWS, W. H.; FLOWERS, J. S.; BAILEY, J. S. Salmonella. In: DOWNES, F. P.; ITO, K. Compendium of methods for the microbiological examination of foods. 4. ed. Washington: APHA, 2001. p. 357-380.

15 ZAR, J. H. Biostatistical analysis. New Jersey: Prentice Hall, 1996. 718 p.

16 AGÊNCIA NACIONAL DE VIGILÂNCIA SANITÁRIA. Regulamento técnico de padrões microbiológicos para alimentos, Resolução RDC No 12, 2001. Disponível em: < http://www.anvisa.gov.br/ e-legis/>. Acesso em 25 out. 2008.

17 SILVA, J.A.; AZERÊDO, G.A.; BARROS, C. M. R; COSTA, E. L.; FALCÃO, M. M. S. Incidência de bactérias patogênicas em carne de frango. Higiene Alimentar; v.16, n. 100, p. 97-101, 2002.

18 CARDOSO, A. L. S. P.; CASTRO, A. G. M.; TESSARI, E. N. C.; BALDASSI, L.; PINHEIRO, E. S. Pesquisa de Salmonella spp, coliformes totais, coliformes fecais, mesófilos, em carcaças e cortes de frango. Higiene. Alimentar, v. 19, n.128:p. 144- 150, 2005.
19 OLSEN, J. E.; BROWN, D. J.; MADSEN, M.; BISGAARD, M. Crosscontamination with Salmonella on a broiler slaughterhouse line demonstrated by use of epidemiological markets. Journal of Applied Microbiology, v. 95, n. 5, p. 826-835, 2003.

20 BAÚ, A. C.; CARVAlHO, J. B.; ALEIXO, J. A. G. Prevalência de Salmonella em produtos de frangos e ovos de galinha comercializados em Pelotas, RS, Brasil. Ciência Rural, v. 31, n. 2, p.303-307, 2001.

21 CARvalho, A. C. F. B.; CORTEZ, A. L. L. Salmonella spp. em carcaças, carne mecanicamente separada, lingüiças e cortes comerciais de frango. Ciência Rural, v. 35, n. 6, p. 1465-1468, 2005.

22 GONÇALVES, P. M. R.; FRANCO, R. M.; ZAMBORLINI, L. C. Enumeração de enterococos e coliformes fecais, pesquisa de Salmonella e indicação presuntiva de Proteus, em cortes e miúdos de frango congelados. Higiene Alimentar, v.12, n. 54, p. 42-47, 1998.

23 JORGENSEN, F.; BAILEY, R.; WILLINS, S.; HENDERSON, P.; WARCING, D. R.; BOLTON, E. J.; FROST, J. A.; WARD, L.; HUMPHREY, T. J. Prevalence and numbers of Salmonella and Campylobacter spp. on cow, whole chicken in relation to sampling methods. International Journal of Food Microbiology, v. 76, n. 1/2, p. 151-164, 2002.

24 MYINT, M. S.; JOHNSON, Y. J.; TABLANTE, N. L.; HECKERT, R. A. The effect of pre-enrichment protocol on the sensitivity and specificity of PCR for detection of naturally contaminated Salmonella in raw poultry compared to conventional culture. Food Microbiology, v. 23, n. 6, p. 599-604, 2006.

25 MATTICK, K. L.; BAILEY, R. A.; JORGENSEN, F.; HUMPHREY, T. J. The prevalence and number of Salmonella in sausages and their destruction by frying, grilling or barbecuing. Journal of Applied Microbiology, v. 93, n. 4, p. 541-547, 2002.

26 ALMEIDA FILHO, E. S.; SAMPAIO, S. C. O. BORGES, N. F.; DELMONDES, E. C.; OZAKI, A. S.; SOUZA, L. C. Pesquisa de Salmonella spp em carcaças de frango (Gallus gallus), comercializadas em feira livre ou em supermercado no município de Cuiabá, MT, Brasil. Higiene Alimentar, v. 17, n. 110, p. 74-79, 2003.

27 SALVATORI, R. U.; BESSA, M. C.; CARDOSO, M. R. I. Qualidade sanitária de embutidos coletados no mercado público central de Porto Alegre-RS. Ciência Rural, v. 33, n. 4, p. 771-773, 2003.

28 MARQUES, S. C.; BOARI, C. A.; BRCKO, C. C.; NASCIMENTO, A. R.; PICCOLI, R. H. Avaliação higiênico-sanitária de lingüiças tipo frescal comercializadas nos municípios de Três Corações e Lavras, MG. Ciências Agrotécnicas, v. 30, n. 6, p. $1120-$ 1123, 2006

29 GIOVANNINI, A.; PRENCIPE, V.; CONTE, A.; MARINO, L.; PETRINI, A.; POMILIO, F.; RIZZI, V.; MIGLIORATI, G. Quantitative risk assessment of 
Salmonella spp. infection for the consumer of pork products in an Italian region. Food Control, v. 15, n. 2, p. 139-144, 2004.

30 MREMA, N.; MPUCHANE, S.; GASHE, B. A. Prevalence of Salmonella in raw minced meat, raw fresh sausages and raw burger patties from retail outlets in Gaborone, Botswana. Food Control, v. 17, n. 3, p. 207-212, 2006.

31 CASTAGNA, S. M. F.; MULLER, M.; MACAGNAN M.; RODENBUSCHE, C. R.; CANAL, C. W.; CARDOSO, M. Detection of Salmonella sp. from porcine origin: a comparison between a PCR method and standard microbiological techniques. Brazilian Journal of Microbiology, v. 36, n. 4, p. 373-377, 2005.

32 SOUMET, C.; GWENNOLA, E.; FACH, P.; COLIN, $P$. Evaluation of different DNA extraction procedures for the detection of Salmonella from chicken products by polymerase chain reaction. Letters in Applied Microbiology, v. 19, n. 5, p. 294-298, 1994. 